\title{
Hydrologic-economic appraisal of life-cycle costs of inter-basin water transfer projects
}

\author{
PH van Niekerk* and JA du Plessis \\ Department of Civil Engineering, University of Stellenbosch, P/Bag X1, MATIELAND 7602, South Africa
}

\begin{abstract}
This article describes research that compares actual water transfers of an inter-basin transfer (IBT) scheme with its original, appraisal stage, prediction. Transfers are shown to be significantly less and also more variable than predicted. Further research reveals that the state of the receiving system has a large bearing on year-to-year decisions regarding water transfers. Past appraisals, following what is called the Incremental Approach, do not adequately consider the stochastic nature of the likely future inter-basin transfer operating regime.

Examination of six case studies, four South African, one Chinese and one Australian, shows that the Incremental Approach is still in general use - despite tools available for an improved approach. A new approach, called the Comprehensive Approach, is proposed to upgrade estimations of variable costs associated with water transfers - often substantial life-cycle cost components of IBTs.

A demonstration of the Comprehensive Approach, by means of an example of an IBT with significant pumping costs associated with water transfers, is provided. Uncertainty regarding future water transfers and associated variable costs are provided for by stochastic simulation modelling. The Incremental Approach is shown to be severely biased with respect to variable costs and it is shown that this bias leads to significantly different estimations of likely life-cycle project costs. Such differences conceivably lead to suboptimal decision-making.
\end{abstract}

Keywords: Water resources, inter-basin water transfer, project appraisal, life-cycle costs, stochastic modelling

\section{INTRODUCTION}

This article reviews the methodology of appraising inter-basin transfer (IBT) projects and proposes an improved approach. To meet water requirements, especially in arid and semi-arid parts of the world, a large number of IBT projects have been constructed or are planned (see extensive listing of IBTs in Snaddon et al. (1999)). In South Africa, due to its geographic and climatic characteristics and coupled to its mineral endowment, the complex interconnected Vaal River System, with the inclusion of a number of IBTs, has been developed over the years to serve the economic heartland of the country (Triebel et al., 1994). In the future, in addition to non-conventional measures such as water demand management and water re-use, more IBTs will be required (Van Rooyen et al., 2010).

IBTs often involve pumping water to overcome differences in elevation. The associated energy costs typically form a significant part of the life-cycle costs of IBTs and it is expected that such energy costs will proportionally increase in future as water has to be sourced from more distant basins (DWA, 2010f). It is therefore important that a robust appraisal methodology be followed when assessing the costs of water transfers of future IBT projects.

\section{METHODOLOGY}

Case study research and secondary data analysis (Van Niekerk, 2013) was employed to examine the accuracy of the appraisal

\footnotetext{
To whom all correspondence should be addressed.

푱 +2782807 4981; e-mail: peter.v.n@mweb.co.za

Received 30 November 2012; accepted in revised form 8 July 2013.
}

approach, called the Incremental Approach, originally followed during the planning of the Usutu-Vaal Government Water Scheme (GWS) (Second Phase) - an IBT scheme. Differences between forecasted and actual water transfers were examined further to identify causal factors. This included an in-depth analysis of 22 years of annual operating analyses. From the results of this research, shortcomings of the Incremental Approach are identified.

Having established the shortcomings of the Incremental Approach, further case study research was conducted to assess whether the planning approach today differs materially from that of the earlier studies, particularly in the light of the far more sophisticated systems analysis modelling tools currently available. Six case studies, four from South Africa, one from the People's Republic of China and one from Australia, were selected.

The four South African case studies were selected on the basis of these being recent investigations conducted by different sets of service providers, well recognised locally and internationally in the field of water resource engineering and management. The two international case studies were chosen on the basis of geographic spread, the recognised status of the agencies involved, and the availability of information. Criteria for the evaluation were developed and these were used to classify the appraisal approaches followed in the case studies.

To address the shortcomings of the Incremental Approach, a new appraisal approach, called the Comprehensive Approach, involving integrated systems simulation and application of decision analysis theory, is proposed. The application of the new approach, as well as the differences in outcomes regarding the estimation of the present value of water transfers and associated variable operational costs, is illustrated by means of an example. 


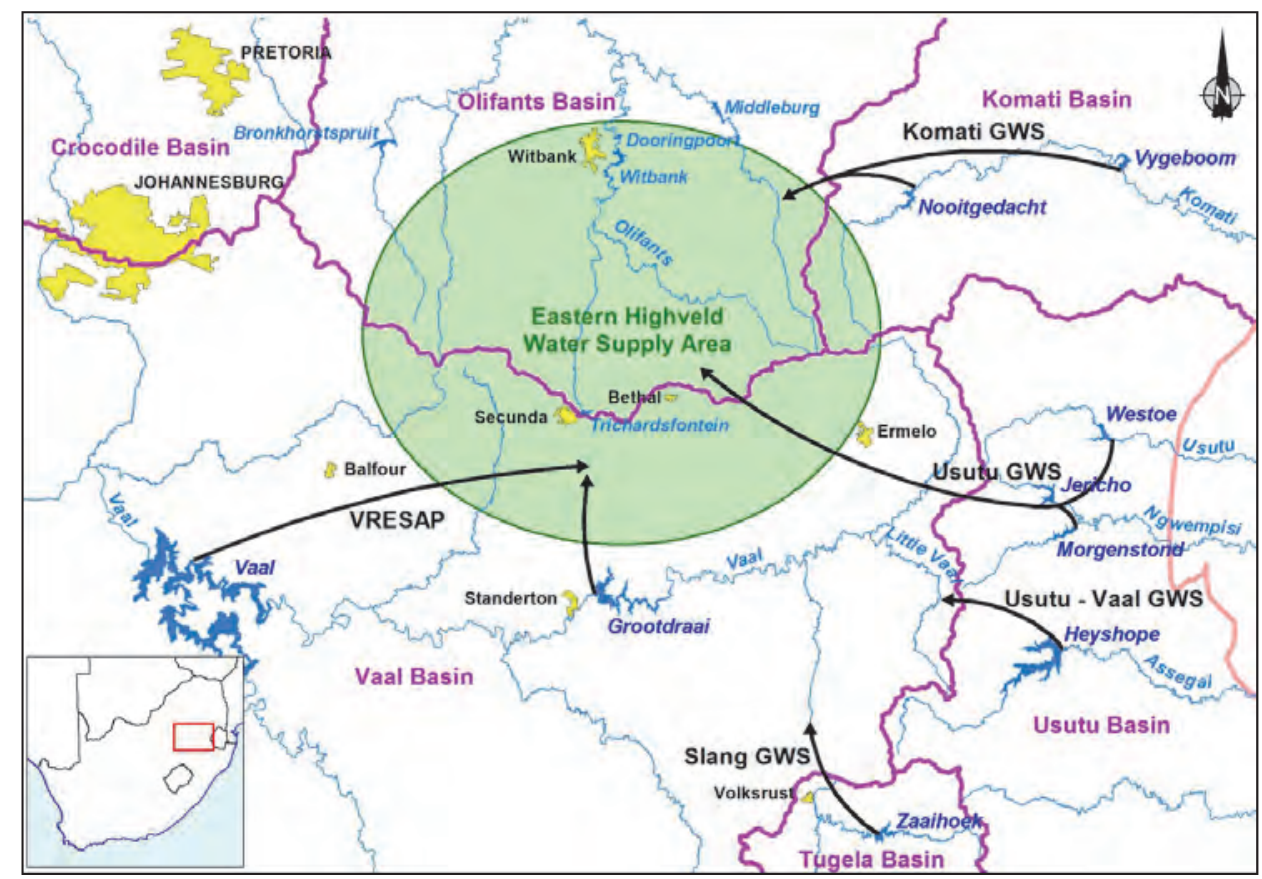

Figure 1 Locality of UsutuVaal GWS (Heyshope Dam) within the upper Vaal River system

\section{RESULTS}

\section{Review of the Incremental Approach: Usutu-Vaal GWS}

Having been in operation for 24 years, the Usutu-Vaal GWS provided a good case for an ex post facto review of the original appraisal approach - the Incremental Approach.

The Usutu-Vaal GWS (Second Phase), described in White Paper (WP) F-'81 (Department of Water Affairs, Forestry and Environmental Conservation, 1981), was an IBT scheme planned and built in the early 1980s to supplement the water resources of the Vaal River system. This IBT, shown in Fig. 1 (along with other IBTs similarly connected), consists of the Heyshope Dam on the Assegai River, a tributary of the Usutu River, and transfer infrastructure to convey water against an elevation difference of $193 \mathrm{~m}$ over the continental divide into the Vaal River catchment, upstream of the Grootdraai Dam.

\section{Water transfers and the Incremental Approach}

The Incremental Approach, depicted in general terms in Fig. 2, is a deterministic planning approach where the growth in demand is such that a new scheme, an IBT in this case, is required to meet requirements beyond time T1. The Incremental Approach assumes that all requirements beyond the capability of the existing system, i.e. the shaded area in Fig. 2, must be met from the new resource. The annual water transfers therefore will exhibit gradual growth, from time T1 until time $\mathrm{T} 2$, and then be capped by the yield capability of the new scheme, $\Delta \mathrm{Y}$. As pumping costs are directly related to quantities transferred, these annual costs exhibit the same pattern.

\section{Actual transfers of the Usutu-Vaal GWS}

The actual annual volumes of water historically transferred from Heyshope Dam are shown in Fig. 3 and compared to the original projection in WP F-'81. Whereas the original projection was for a smoothly growing transfer, capped by the capacity of the transfer scheme, the actual transfers exhibited an

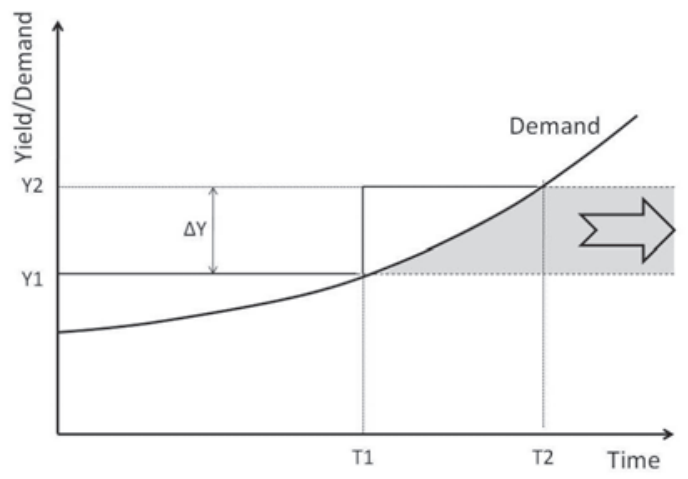

Figure 2

Determining pumping costs with the Incremental Approach of IBT project appraisal

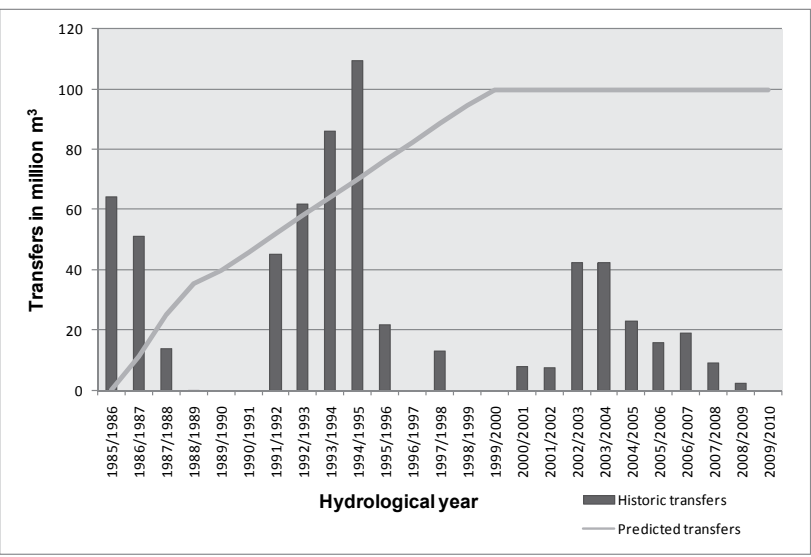

Figure 3

Usutu-Vaal GWS (Second Phase): Historic water transfers from Heyshope Dam against transfers predicted

erratic pattern. It was also found that the average transfer was 26.5 million $\mathrm{m}^{3} / \mathrm{a}$ over the period - only $35 \%$ of what had been envisaged at the planning stage. 


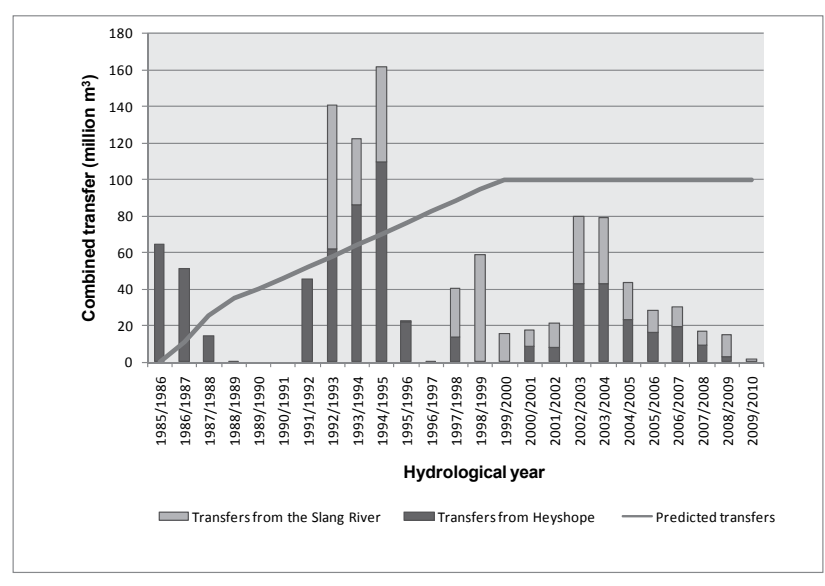

Figure 4

Combined historic water transfers from the Heyshope Dam and the Zaaihoek Dam on the Slang River

\section{Reasons for differences between predicted and actual transfers}

Plausible explanations for the differences between predicted and actual transfers were sought by examining possible impacts from other resource developments in the basin, changes in demand and source constraints.

A resource development that did have an effect was another IBT completed in 1988, the Slang River GWS (DWA, 1986). This scheme, also shown in Fig. 1, was built primarily to supply water from the Zaaihoek Dam on the Slang River to a new power station, but the facility to transfer water to the upper reaches of the Vaal River was included in its design. Actual water transfers from Zaaihoek Dam to Grootdraai Dam over the period 1990 to 2010 were combined with the transfers from Heyshope Dam to obtain a more complete perspective as depicted in Fig. 4.

The erratic nature observed in Fig. 3 is, if anything, reinforced by the transfers from the Slang River. The combined average transfer of 42.5 million $\mathrm{m}^{3} / \mathrm{a}$ reduced the discrepancy somewhat, but it remains significantly less than the average of 73.5 million $\mathrm{m}^{3} / \mathrm{a}$ water transfer originally envisaged for the period.

Another scheme, the Vaal River Eastern Subsystem Augmentation Project (VRESAP) (see Fig. 1), linked the Grootdraai Dam subsystem to the Vaal Dam. The VRESAP was completed in 2009 and made no significant contribution during the period under observation.

An examination of changes in demand revealed that growth had been slower than predicted. This would explain the lower volume in water actually transferred. However, the historic firm yield of Grootdraai Dam had been reassessed in 2001 and found to be only $77 \%$ of the earlier estimate (DWAF, 2001). The incremental water requirement, following the approach as depicted in Fig. 2, would in retrospect have averaged 61.4 million $\mathrm{m}^{3} / \mathrm{a}$ for the equivalent period, which still meant that the actual transfers fell significantly short - by some $30 \%$.

As regards the possibility of supply constraints causing lower transfers, records showed that both the Heyshope and Zaaihoek Dams had been relatively full over the period, indicating that there had been no impediment, from a source perspective, in transferring water to the Vaal River Basin.

A detailed tracing of the annual operation of the Vaal River Supply System, with the inclusion of the Grootdraai Dam subsystem, was required to shed further light on the reasons for the observations depicted in Fig. 3 and Fig. 4.

\section{Annual operational systems analyses}

Annually, at the end of the rainy season, the DWA undertakes an analysis of the Vaal River System in order to set the operational regime for the following year. This, so-called, Annual Operating Analysis (AOA) takes into account the state of the system (i.e. storage of each dam) as at 1 May of each year. The analysis is conducted soon afterwards.

The AOA entails running DWA's Water Resources Planning Model (WRPM) to simulate the behaviour of the Integrated Vaal River System (IVRS), usually for 1000 stochastic timeseries of flows of 20 -year duration. This is repeated for various scenarios to test the impact of variations in operational rules, different growth projections, and possible changes to the configuration of the system.

The WRPM is a South African developed systems analysis simulation tool to determine the probabilistic yield characteristics of complex water resource systems. It can accommodate multiple demand centres (i.e. yield channels), take into account growth in demand and changes in land use, allow expansion of the system at future dates, deal with quality constraints, and impose curtailments. Its great advantage is that it explicitly provides information on future risks associated with postulated management and intervention scenarios. It is used for operational as well as planning purposes.

Annual reports covering a period of 22 years, starting 1990/91 and ending 2011/12, were studied to see how the IBTs from Heyshope Dam and Zaaihoek Dam were operated in the light of the conditions in the rest of the IVRS during that period, and in particular that of the Vaal River Eastern SubSystem (VRESS) to which these IBTs are linked. A time-line perspective could be obtained of the four variables that influenced the decisions related to the transfers from these IBTs; the state of the system at decision date, the changes in system configuration and capacity, the projections in demand on the system for the short and medium term and the levels of assurance of water supply.

It was found that the state of the system, in particular the level of water in storage in Grootdraai Dam, had been the dominant determinant in the decisions related to the transfers from Heyshope and Zaaihoek Dams. The state of the system at the decision date is influenced by the inflows the dams received in the preceding period and the abstractions that were made. Of these the inflows are by far the dominant factor; abstractions were more stable and predictable.

During the 22-year period the system storage generally remained at fairly high levels, except for a period between $1992 / 93$ and 1995/96 when a drought occurred. This drought was of such a severity that restrictions had to be imposed on all water users on 1 April 1995. Irrigation water users were restricted by $40 \%$, municipal users by $20 \%$, mines and the SASOL oil-from-coal facility by $10 \%$ and Eskom power stations by $5 \%$. After exceptionally good rains in November 1995 the drought was broken. Restrictions were lifted in January 1996.

For the four years of the drought, large quantities of water were transferred from the Heyshope and the Zaaihoek dams. Problems with the pumps at the Geelhoutboom pumping station at Heyshope prevented continuous transfer at maximum capacity during these years. The policy at first was to keep all the water transferred in Grootdraai Dam, i.e., not to support the rest of the system. When Grootdraai Dam filled 
completely (largely as a result of the transfers) it was decided to continue pumping as there were delays in bringing the Lesotho Highlands Water Project (LHWP) on stream, keeping Grootdraai Dam full and the spills to augment Vaal Dam. All transfers were stopped in December 1995 due to the system having recovered completely from the drought.

After the drought years of 1992/93 to 1994/95 the operating rule for transfers to Grootdraai Dam followed a fairly consistent pattern; the two transfer projects were treated in tandem and similar recommendations made for transfers from the Heyshope Dam and the Zaaihoek Dam for the year that lay ahead. These recommendations were based on the likelihood that water shortages may develop in the short to medium term, and typically read as follows: 'Inter-basin transfers from Zaaihoek Dam and Heyshope Dam to Grootdraai Dam to be made when Grootdraai Dam is below "X"\% of its net full supply storage.'

For eleven out of the sixteen years since the drought, ' $\mathrm{X}$ ' was set at $75 \%$. During these years the starting storages of Grootdraai Dam averaged $96.1 \%$. For four of the years a $90 \%$ rule was adopted. The average starting storage in these cases was $95.2 \%$, which is not significantly different to the average for the $75 \%$ rule. It is noticed that three of these years occurred in the five years before the VRESAP pipeline started at the end of 2008 to augment the system from the Vaal Dam. This is consistent with the behaviour that can be expected of a system that is moving closer to its maximum safe yield capacity, with a growing demand and just prior to the system being augmented.

Only in a few isolated instances did the state of storage in the rest of the system, other than that of Grootdraai Dam, influence the operating rule adopted for the transfers from
Zaaihoek Dam and Heyshope Dam. During the drought years of 1992/93 to 1994/95 the rule was set that transfers should cease when the Grootdraai Dam reached 95\%, but, due to the very low state of the rest of the system in January 1994, it was decided to continue with the pumping despite the fact that Grootdraai Dam was full. This effectively meant that the Zaaihoek and Heyshope transfers supported the Vaal Dam for the period January 1994 to December 1996. For the rest of the 22-year record under examination, the state of storage in Grootdraai Dam determined the transfer regime from Zaaihoek and Heyshope.

\section{Case studies of current planning practice}

The names and other details regarding the four South African case studies selected are provided in Table 1. Similar information regarding the two international case studies is provided in Table 2.

The criteria selected to evaluate the appraisal methodology applied in each IBT case were the following:

a) Whether the assumption was made that all incremental demand, beyond the yield capability of the existing system, was to be supplied from the IBT and subsequent water resource capacity expansion

b) Whether an analysis had been undertaken that included both the source catchment and the receiving system

c) If so, whether the analysis included the simulation of annual operational decision-making

d) If so, whether the transfers due to the IBT were identified and the time-series used in further analysis.

\begin{tabular}{|l|l|l|l|l|l|}
\hline \multicolumn{7}{|c|}{ RSA case studies } \\
\hline Number & \multicolumn{1}{|c|}{ Name of project } & $\begin{array}{l}\text { Date of } \\
\text { completion }\end{array}$ & Service provider & Client & Reference \\
\hline $\begin{array}{l}\text { Case } \\
\text { Study 1 }\end{array}$ & $\begin{array}{l}\text { Mooi-Mgeni Transfer Scheme } \\
\text { Phase 2: Selection of water transfer } \\
\text { system }\end{array}$ & March 2009 & BKS (Pty) Ltd & TCTA & TCTA, 2009 \\
\hline $\begin{array}{l}\text { Case } \\
\text { Study 2 }\end{array}$ & $\begin{array}{l}\text { Mkomazi-Mgeni Transfer Scheme } \\
\text { Pre-feasibility Study }\end{array}$ & May 1999 & $\begin{array}{l}\text { Ninham Shand Consulting } \\
\text { Engineers }\end{array}$ & $\begin{array}{l}\text { DWAF and } \\
\text { Umgeni Water }\end{array}$ & DWAF, 1999 \\
\hline $\begin{array}{l}\text { Case } \\
\text { Study 3 }\end{array}$ & $\begin{array}{l}\text { Wokolo and Crocodile (West) } \\
\text { (MCWAP) }\end{array}$ & $\begin{array}{l}\text { September } \\
2010\end{array}$ & $\begin{array}{l}\text { Africon in association with Kwezi } \\
\text { V3 Engineers, Vela VKE, and WRP } \\
\text { Consulting Engineers }\end{array}$ & DWA & $\begin{array}{l}\text { DWA, 2010a, } \\
\text { DWA, 2010b } \\
\text { DWA, 2010c } \\
\text { DWA, 2010d }\end{array}$ \\
\hline $\begin{array}{l}\text { Case } \\
\text { Study 4 }\end{array}$ & $\begin{array}{l}\text { Vaal River Water Resource } \\
\text { Development Project: Comparative } \\
\text { Study between Lesotho Highlands } \\
\text { Water Project Phase II (LHWP II) } \\
\text { and Thukela Water Project (TWP) }\end{array}$ & October 2010 & $\begin{array}{l}\text { ACER (Africa), BKS, DMM } \\
\text { Development Consultants, Golder } \\
\text { Associates Africa and WRP } \\
\text { Consulting Engineers }\end{array}$ & DWA & $\begin{array}{l}\text { DWA, 2010e } \\
\text { DWA, 2010g }\end{array}$ \\
\hline
\end{tabular}

\begin{tabular}{|l|l|l|l|l|l|}
\hline \multicolumn{5}{|c|}{ TABLE 2 } \\
\hline Number & Name of project & Date of completion & $\begin{array}{l}\text { Lead firm/ } \\
\text { investigating agency }\end{array}$ & Client & Reference \\
\hline $\begin{array}{l}\text { International } \\
\text { Case Study 1 }\end{array}$ & $\begin{array}{l}\text { Wanjiazhai } \\
\text { Water Transfer } \\
\text { Project (WWTP) }\end{array}$ & $\begin{array}{l}\text { Appraisal 1997 } \\
\text { Implementation } \\
\text { completion and } \\
\text { results 2007 }\end{array}$ & World Bank & $\begin{array}{l}\text { Government of the } \\
\text { People's Republic } \\
\text { China }\end{array}$ & $\begin{array}{l}\text { World Bank, 1997 } \\
\text { World Bank, 2007 }\end{array}$ \\
\hline $\begin{array}{l}\text { International } \\
\text { Case Study 2 }\end{array}$ & $\begin{array}{l}\text { Water augmen- } \\
\text { tation to South } \\
\text { East Queensland, } \\
\text { Australia }\end{array}$ & $\begin{array}{l}\text { Various reports - } \\
\text { from 2006 to 2010 }\end{array}$ & $\begin{array}{l}\text { Various Australian } \\
\text { consultancies }\end{array}$ & $\begin{array}{l}\text { Government of } \\
\text { Queensland/ } \\
\text { Queensland Water } \\
\text { Commission }\end{array}$ & $\begin{array}{l}\text { Queensland Government, 2006 } \\
\text { Marsden Jacobs Associates, 2007a } \\
\text { Marsden Jacobs Associates, 2007b } \\
\text { Queensland Water Commission, 2010 }\end{array}$ \\
\hline
\end{tabular}


If the answer to a) was in the affirmative or any of the criteria b) to d) were in the negative, the conclusion was drawn that the Incremental Approach had been followed. Key information about each case study is summarised in Table 3.

\section{TABLE 3}

\section{Summary of case studies}

\section{Description of case study}

RSA Case Study 1: Mooi-Mgeni Transfer Scheme Phase 2 (MMTS2): Selection of water transfer system.

This proposed IBT scheme entailed a dam at the site Spring Grove on the Mooi River and a conveyance structure to deliver water to the Mpofana River, upstream of Midmar Dam. The investigation compared conveyance by gravity through a tunnel against pumping (pumping station and pipeline) against a total head of $98 \mathrm{~m}$.

\section{RSA Case study 2: Mkomazi-Mgeni Transfer Scheme Pre-} Feasibility Study.

This proposed IBT scheme was envisaged to follow the MMTS-2 (see above), augmenting the Mgeni Water Supply System from the Mkomazi River.

Two major dam options, one at Impendle and the other at Smithfield, were examined, as were different possible transfer routes. From Impendle Dam it was envisaged that water can be conveyed by gravity tunnel to the Mgeni River above Midmar Dam, while water from the Smithfield Dam could be transferred by pumping against an average head of $48 \mathrm{~m}$ into a tunnel that would link it to the water supply system of Umgeni Water.

RSA Case Study 3: Mokolo and Crocodile (West) Water Augmentation Project (MCWAP).

This proposed IBT scheme will transfer water from the Crocodile (West) River to the Mokolo River supply area near the town of Lephalale to meet growing water requirements of expanding coalbased developments (power stations, mines and industries). The total transfer distance is $123 \mathrm{~km}$ and the dynamic pumping head $275 \mathrm{~m}$.

RSA Case Study 4: Vaal River Water Resource Development Project: Comparative Study between LHWP II and Thukela Water Project (TWP).

Both these IBTs were considered for augmentation of the water resources of the Vaal River Supply System. Whereas the LHWP II is a gravity scheme the TWP involves pumping of the water over the continental divide. The proposed TWP comprises a large dam, the Jana Dam, in the Thukela River, to be followed later by the Mielietuin Dam on the Bushmans River, and associated pipelines and pumping stations to transfer water to the existing Drakensberg Project. This hydro-electric pump-storage facility will be used to transfer the water across the divide into the Sterkfontein Dam in the upper reaches of the Wilge River, a tributary of the Vaal River. In total this will require overcoming an elevation difference of $1030 \mathrm{~m}$.

International Case Study 1: Wanjiazhai Water Transfer Project (WWTP).

The first phase of WWTP, which transfers water from the Wanjiazhai Dam in the Yellow River basin to the Fen River basin in the Shanxi Province in the northeast of China, was completed in 2005 . Its design capacity is 640 million $\mathrm{m}^{3} / \mathrm{a}\left(25.8 \mathrm{~m}^{3} / \mathrm{s}\right)$ and the scheme comprises tunnels with a total length of $144 \mathrm{~km}$ and 5 pumping stations to overcome a total static head of $648 \mathrm{~m}$. It supports, in particular, the highly industrialised area round the provincial capital, Taiyuan City. The World Bank was involved in the financing of the project. Prior to implementation it conducted an appraisal of the project and followed it up, after completion, with an evaluation report.

\section{Evaluation result}

It was assumed that all incremental demand, beyond the yield capability of the existing system, had to be supplied from the Spring Grove Dam and/or the subsequent Mkomazi River dams. Although a full system analysis with the inclusion of the proposed IBT project was undertaken it did not include a simulation of annual operational decisionmaking and a time-series analysis of likely water quantities to be transferred.

It was assumed that a shortage of water would occur every year in the future and that this would have to be made good by transfers from the Mkomazi basin. The shortages to be met were estimated by subtracting the available yield, before inclusion of the Mkomazi IBT project, from the total water requirement. A full system analysis with the inclusion of both the receiving basin and the proposed IBT project was not undertaken and therefore no simulation was done of annual operations and likely water quantities to be transferred.

Variable costs associated with the transfers of water from the Crocodile River system were assumed to be directly related to the shortfall predicted. The annual shortfalls were determined by subtracting the available yield of Mokolo Dam from the annual water requirements. A full system analysis with the inclusion of both the receiving basin and the proposed IBT project was not undertaken. No simulation was accordingly done of annual operations and likely water quantities to be transferred.

The annual transfer requirements from the TWP were equated to the projected shortfalls in the Vaal River Supply System. The latter were derived by subtracting the system yield from the projected Vaal system demand, capped by the net yield of Jana Dam. A full system analysis with the inclusion of both the receiving basin and the proposed IBT project was not undertaken. No simulation of annual operations and likely water quantities to be transferred was accordingly performed.

The appraisal assumed that the required annual water transfer for each year in the future would be exactly equal to the deficit projected, the latter being the difference between the projected water demand and the sustainable yield of the local water resources. Neither of the two World Bank assessments considered the need for an integrated hydrological assessment of the source and receiving basin, jointly, in a total systems context. No simulation of annual operations, and likely water quantities to be transferred, was performed. 


\begin{tabular}{|l|l|}
\hline Description of case study & Evaluation result \\
\hline $\begin{array}{l}\text { International Case Study 2: Water augmentation to South East } \\
\text { Queensland, Australia. }\end{array}$ & $\begin{array}{l}\text { It was found, by inference from contextual analysis } \\
\text { as not all data were reported, that the assumption }\end{array}$ \\
$\begin{array}{l}\text { South East Queensland (SEQ), with the city of Brisbane, experienced its } \\
\text { worst drought on record in the first decade of this century. Severe water } \\
\text { restrictions were imposed and the Department of Natural Resources } \\
\text { and Water of the Government of Queensland embarked on compre- } \\
\text { hensive investigations of options to augment the water resources of the } \\
\text { affected area. A number of sites were identified for possible dams to } \\
\text { supplement the existing Wivenhoments beyond exist- } \\
\text { Brisbane and surrounding areas with water. Some of these schemes } \\
\text { involved IBTs and significant pumping. }\end{array}$ & $\begin{array}{l}\text { resources. No comprehensive system analysis with the } \\
\text { inclusion of the receiving basin as well as the proposed } \\
\text { IBT projects was done. No simulation was undertaken } \\
\text { of annual operations and likely water quantities to be } \\
\text { transferred. }\end{array}$ \\
\hline
\end{tabular}

\section{DISCUSSION}

In the case study of the Usutu-Vaal GWS IBT the lower quantity of water actually transferred, as compared to what had originally been predicted, as well as the erratic nature of actual transfers as compared to the smooth growth originally assumed, could be explained by tracing the annual operations of the project over 24 years. It was shown that the Heyshope, as well as Zaaihoek, transfers were primarily determined by the state of storage in the Grootdraai Dam, and that the latter storage was dependent on the inflow into the dam, i.e., the run-off arising in its catchment (excluding the water transferred in, as this is not an independent variable). By extension therefore the Heyshope and Zaaihoek transfers were dependent on the run-offs that occurred in the catchment of the Grootdraai Dam, i.e., the receiving catchment. As these run-offs are inherently uncertain, hydrological uncertainty similarly characterises water transfers.

In the original planning of the Usutu-Vaal IBT, the investigation into the annual operating analyses showed that the assumption that all incremental water requirements, beyond the yield capability of Grootdraai Dam, would be required to be met from transfers had been incorrect. The Incremental Approach led to an overestimation of the quantities of water to be transferred and, by the same token, operational costs. The correct appraisal approach would be to treat water transfer as a stochastic variable. The Incremental Approach, being a deterministic approach to IBT scheme appraisals, does not capture the essential characteristic of future water transfers - these being erratic and of an uncertain nature.

Whether the Incremental Approach was currently still in use was examined next. The four South African cases each involved an investigation into options to augment the water resources of an existing water supply system by a possible interbasin transfer. Examination of their reports revealed, for each case, that:

- Simulation modelling was undertaken to establish the available yield of the existing system

- Simulation modelling was undertaken in the source catchment to establish the available yield that could be transferred

- The water to be transferred annually was assumed to be equal to the deficit predicted for that year in the future, capped by the available transfer yield when the deficit reached and exceeded the yield

- The annual transfer costs were directly related to the quantities being transferred

The first of the international case studies, the Wanjiazhai Water Transfer Project in China, was based on documents compiled pre- and post-implementation of the project by the World Bank. It was found that:

- The transfer project was expected to provide all incremental water beyond the yield of the receiving basin

- Annual transfers were expected to exhibit a pattern of smooth growth, coinciding with water demand growth, until capped by the transfer capacity of the scheme

- Costs to transfer the water were directly related to the annual quantities being transferred

- These costs were included in the economic appraisal

Examination of the South East Queensland (SEQ) reports regarding augmenting resources for the City of Brisbane and surrounds showed that:

- The assumption was made that all water requirements beyond existing system yield capacity had to be provided from new resources

- The determinations of the additional availability of yield from potential augmentation options were not done in a systems context

The approach followed in all six case studies was therefore analogous to the Incremental Approach, supporting the thesis that the latter approach is currently still generally in use.

\section{The proposed Comprehensive Approach}

An improved approach, herein called the Comprehensive Approach, is proposed to explicitly address the probabilistic characteristics of water transfers and, following this, to upgrade the estimation of the costs associated with such transfers.

The Comprehensive Approach firstly requires the integrated analysis of the source basin and the receiving system, in combination. A simulation model, such as the WRPM, must be set to record water transfers, at suitable, typically monthly, intervals. The model is then employed to obtain simulated sequences of future water transfers of IBT schemes under consideration. With stochastic hydrological data input the transfer data sequences thus generated will exhibit characteristics similar to the actually observed water transfers of existing IBT projects.

With the synthetically generated water transfer data as input into a life-cycle cost model, the analyst is able to obtain a representation of the probabilistic characteristics of the lifecycle costs of an IBT scheme under consideration. Such output would form an important input into further economic investigations, such as a cost-benefit analysis, to ascertain the feasibility of a proposed IBT scheme.

To illustrate the application of the Comprehensive Approach, and to compare it to the Incremental Approach, 


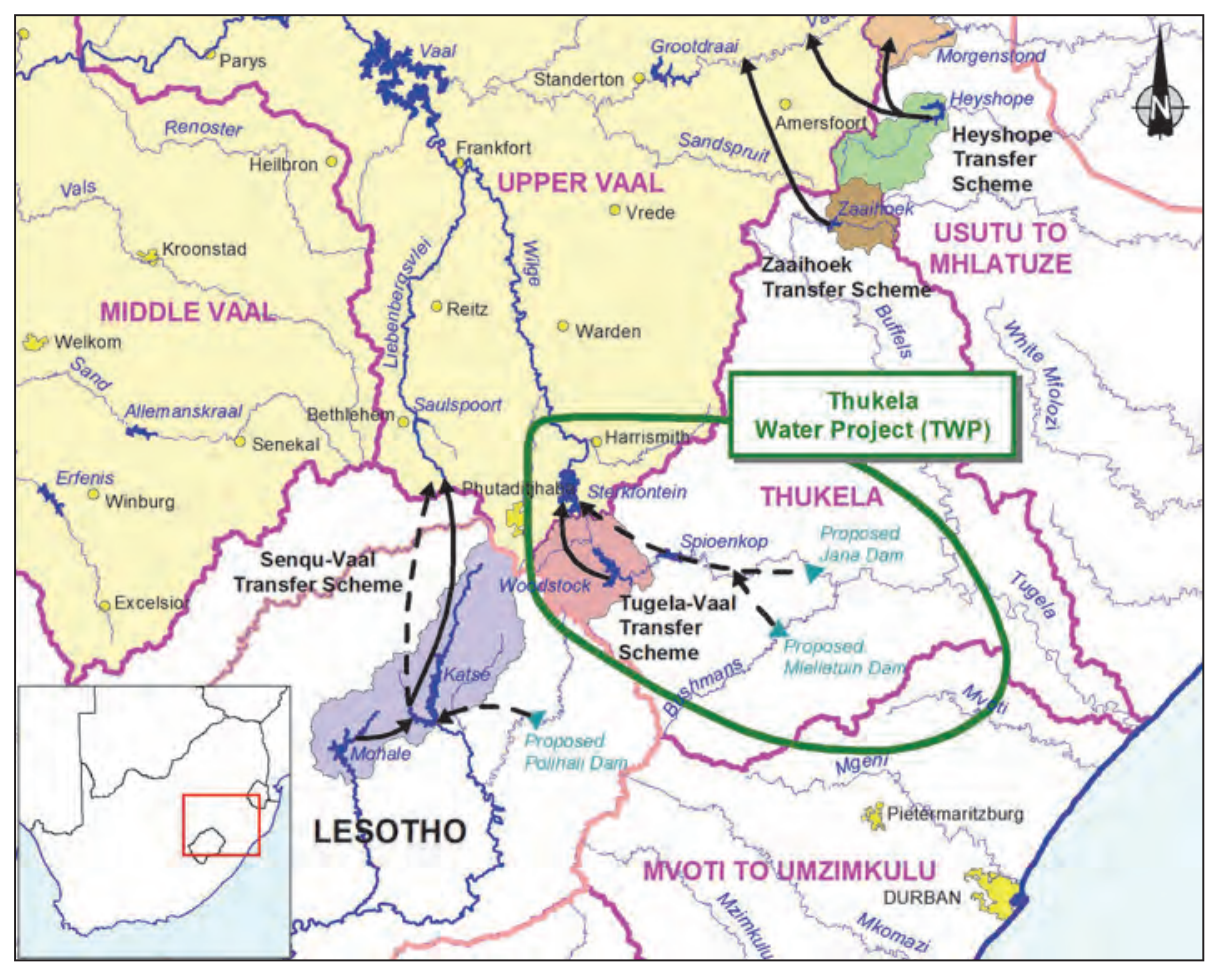

Figure 5

Map of the TWP and its Lesotho Highlands Water Project (Polihali Dam) as alternative

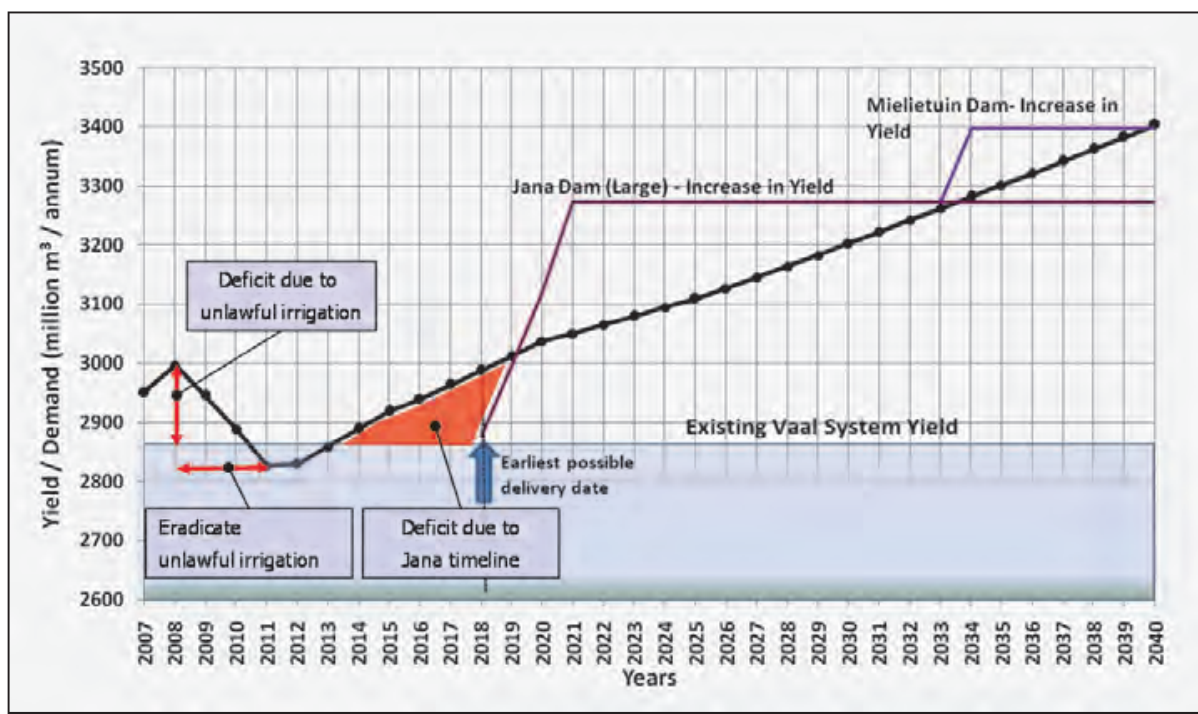

Figure 6 Projected Vaal River System water demands and possible interventions the example of the Thukela Water Project (TWP) in South Africa is presented.

\section{Example: the Thukela Water Project (TWP)}

The TWP was briefly described in Table 3. It was considered as an IBT to link to the existing Vaal River System (also described above) and its locality is shown in Fig. 5.

A number of scenarios of future water demands in the supply area of the Vaal River System were developed, one of which, shown in Fig. 6, is used further in this example. Also shown in Fig. 6, in order to meet the requirement, is Jana Dam implemented as a first phase by 2018 - the earliest date possible - followed by the Mielietuin Dam in 2034. (To overcome the early shortages, additional measures, such as water demand management, would be required). In the example presented here, the first phase, Jana Dam and associated transfer works, is considered.

\section{TWP example - results with Incremental Approach}

To start with, the currently used Incremental Approach will be followed to determine the life-cycle costs of the first phase of the TWP. This means that the assumption is made that all future water requirements, above the existing Vaal System Yield line shown in Fig. 6, have to be sourced from Jana Dam and transferred to the Vaal River basin. The annual volumes thus required to be transferred are shown in Fig. 7.

A shadow price for electricity of 82.2 cents per $\mathrm{kWh}$ for a base date of October 2007 was established for the purpose of the economic appraisal, from recent work into the future marginal cost of water for South Africa (DWA, 2010f). Accordingly, to pump water across to the Vaal River basin, a shadow cost was calculated as R2.87 per $\mathrm{m}^{3}$. The resultant annual pumping costs, as well as all other operating and capital costs, were discounted at $8 \%$ per year - the social discount rate recommended 


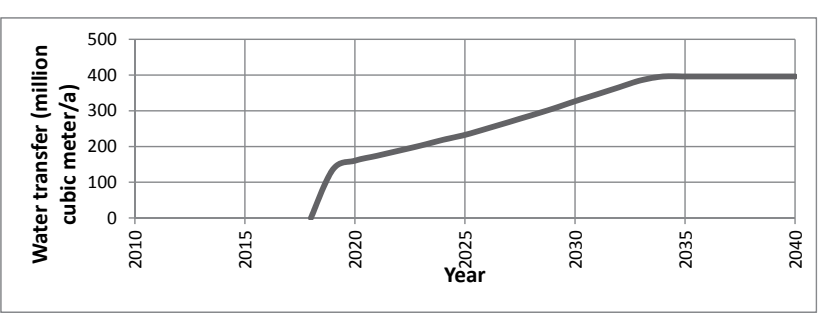

Figure 7

TWP water transfers according to the Incremental Approach

for Government Water Schemes in South Africa (Conningarth Economists, 2007) - to obtain present values (PVs) of the costs associated with TWP during its economic life shown in Table 4. (Note: currency is in South African Rand (R).)

\begin{tabular}{|l|c|}
\hline \multicolumn{2}{|c|}{ TABLE 4 } \\
Incremental Approach: Present value of \\
TWP costs (8\% discount rate, October \\
2007 base date)
\end{tabular}

\section{TWP example - results with} Comprehensive Approach

The Comprehensive Approach requires first an analysis of the system as a whole, i.e., inclusive of the source and receiving systems

Using stochastically generated hydrological sequences and the demand scenario shown in Fig. 6 as input to the WRPM, and 995 repeated simulations of the integrated system for the period 2010 to 2050, gave 995 stochastic sequences of 41 years each, capturing the operational procedures likely to apply in practice (Van Rooyen, 2012). For each month the quantity of water transferred was recorded.

Figure 8 graphically depicts the annual transfer records of the first five of the 995 sequences of water transfers. As can be seen, no clear pattern emerges except that the graphs can be typified as being of an erratic nature, bounded by zero and the maximum transfer capacity of the scheme. Visually these appear very similar in character to the actual transfer records in Fig. 3 and Fig. 4.

Using the shadow pumping costs of $\mathrm{R} 2.87$ per $\mathrm{m}^{3}$ as before, the 995 stochastic sequences of water transfer are next converted to 995 sequences of annual water transfer costs. For each sequence of 41-year length, a PV is determined at $8 \%$ per year discount rate (base date October 2007). Figure 9 shows the cumulative probability density function of the resultant 995 PVs. Some statistical parameters, including the $10^{\text {th }}$ and $90^{\text {th }}$ percentile values, being the recommended stochastic range by Matheson and Howard (1983) to consider the effect of fluctuations of a state variable, are also summarised in Table 5.

\begin{tabular}{|c|c|c|}
\hline \multicolumn{3}{|c|}{$\begin{array}{c}\text { TABLE } 5 \\
\text { Statistical parameters of PVs of electricity costs } \\
\text { of set of } 995 \text { sequences of water transfers ( } 8 \% \\
\text { p.a. discount rate) }\end{array}$} \\
\hline \multicolumn{2}{|l|}{ Parameter } & $\begin{array}{l}\text { Present value } \\
\text { (R million) }\end{array}$ \\
\hline \multicolumn{2}{|l|}{ Median } & 405 \\
\hline \multicolumn{2}{|l|}{ Average } & 454 \\
\hline \multicolumn{2}{|l|}{ Standard deviation } & 283 \\
\hline \multirow[t]{2}{*}{ Stochastic range: } & $10^{\text {th }}$ Percentile & 159 \\
\hline & $90^{\text {th }}$ Percentile & 816 \\
\hline
\end{tabular}


Figure 8

Graphical depiction of first five of 995 transfer sequences 


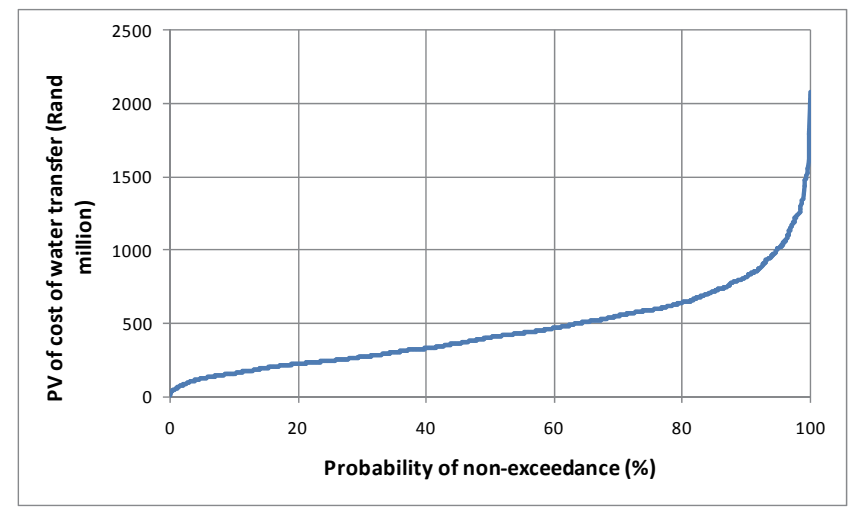

Figure 9

Probability of PV of pumping costs for total set of 995 sequences (8\% discount rate)

As inter-basin water transfer projects typically are undertaken as public works, the decision-maker will be the government. Considering decision analysis theory, a government would be viewed as risk-indifferent (Howard, 1980), and therefore assumed to be an expected value decision-maker: the expected value would be the unbiased rational choice exercised. The expected PV of the cost of the future TWP water transfers is therefore the average value, i.e. R454 million. With the inclusion of the fixed costs of R6753 million the total expected life-cycle costs, using the Comprehensive Approach, is R7207 million.

\section{Comparison of approaches}

The results of the calculations, following the two approaches, are summarised in Table 6. As can be seen, the PV of the Incremental Approach exceeds even the $90^{\text {th }}$ percentile value of the Comprehensive Approach, indicating the extreme bias of the former approach.

TABLE 6

Summary of comparison of PVs of the TWP following the Incremental Approach vs. Comprehensive Approach (8\% p.a. discount rate)

\begin{tabular}{|c|c|c|}
\hline & & $\begin{array}{c}\text { PV of life-cycle } \\
\text { costs } \\
\text { (R million) }\end{array}$ \\
\hline \multicolumn{2}{|l|}{ Incremental Approach } & 10836 \\
\hline \multirow[t]{2}{*}{ Comprehensive Approach } & Expected value & 7207 \\
\hline & Stochastic range & $6912-7569$ \\
\hline
\end{tabular}

\section{CONCLUSION}

South Africa has a number of IBTs operating for more than 20 years. Case study research was conducted into one such IBT, the Usutu-Vaal Government Water Scheme, which transfers water from the Heyshope Dam to the upper Vaal River basin. Actual water transfers were compared to those originally predicted at the appraisal stage and were found to be considerably less and more variable than initially envisaged. As the cost of pumping water often constitutes substantial life-cycle cost components, this raised the question as to whether the approach used at the time, named here the Incremental Approach, adequately captured the cost of transferring the water.

The Incremental Approach assumed that all water beyond the capability of the existing system had to be provided from the proposed new scheme. Detailed tracing back of past operating decisions showed this to be a simplistic assumption; the state of the receiving system had a large bearing on decisions regarding water quantities to be transferred.

Further research into six case studies, four South African, one Chinese and one Australian, showed that the Incremental Approach is still in general use - despite tools available for an improved approach.

A new approach, called the Comprehensive Approach, is proposed. Uncertainty regarding future water transfers and associated variable costs is provided for by stochastic simulation modelling. Decision analysis theory is applied to obtain the expected value and stochastic range of variable costs.

The application of the Comprehensive Approach, as opposed to the Incremental Approach, was demonstrated by means of an example with significant pumping costs associated with water transfers. It was shown that the Incremental Approach is severely biased with respect to variable costs and that this bias leads to significantly different estimations of likely life-cycle project costs. Such differences conceivably lead to suboptimal decision-making.

\section{ACKNOWLEDGEMENTS}

The authors wish to thank the Department of Water Affairs, South Africa, for the use of its records, documents and drawings.

\section{REFERENCES}

CONNINGARTH ECONOMISTS (2007) A Manual for Cost Benefit Analysis in South Africa with Specific Reference to Water Resource Development. (2 ${ }^{\text {nd }}$ edn.). WRC Report No. TT 305/07. Water Research Commission, Pretoria.

DEPARTMENT OF WATER AFFAIRS, FORESTRY AND ENVIRONMENTAL CONSERVATION (SOUTH AFRICA) (1981) White Paper F-'81: Report on the Proposed Usutu-Vaal River Government Water Scheme Second Phase. Government Printer, Pretoria.

DWA (DEPARTMENT OF WATER AFFAIRS, SOUTH AFRICA) (1986) White Paper E-'86: First Supplementary Report on the Proposed Slang River Government Water Scheme (Zaaihoek Dam). Government Printer, Pretoria.

DWA (DEPARTMENT OF WATER AFFAIRS, SOUTH AFRICA) (2010a) Mokolo and Crocodile (West) Water Augmentation Project (MCWAP) Feasibility Study: Report 12, Phase2 Feasibility Stage. Report No. P RSA D000/00/8309. Department of Water Affairs, Pretoria.

DWA (DEPARTMENT OF WATER AFFAIRS, SOUTH AFRICA) (2010b) Mokolo and Crocodile (West) Water Augmentation Project (MCWAP) Feasibility Study: Main Report. Report No. P RSA A000/00/8109). Department of Water Affairs, Pretoria.

DWA (DEPARTMENT OF WATER AFFAIRS, SOUTH AFRICA) (2010c) Mokolo and Crocodile (West) Water Augmentation Project (MCWAP) Feasibility Study: Report 6, Water Transfer Scheme Options. Report No. P RSA A000/00/9309. Department of Water Affairs, Pretoria.

DWA (DEPARTMENT OF WATER AFFAIRS, SOUTH AFRICA) (2010d) Mokolo and Crocodile (West) Water Augmentation Project (MCWAP) Feasibility Study: Report 2, Water Resources. Report No.P RSA A000/00/8909. Department of Water Affairs, Pretoria.

DWA (DEPARTMENT OF WATER AFFAIRS, SOUTH AFRICA) (2010e) Vaal River WRDP: Comparative Study between LHWP II and Thukela Water Project: Main Report. Report No. P RSA C000/00/12009/1. Department of Water Affairs, Pretoria.

DWA (DEPARTMENT OF WATER AFFAIRS, SOUTH AFRICA) (2010f) Assessment of the ultimate potential and future marginal cost of water resources in South Africa. Report No P RSA 000/00/12610. Department of Water Affairs, Pretoria. URL: 
<http://www.dwaf.gov.za/Documents/Other/Water\%20Resources/ Assessment $\% 20$ of $\% 20$ Future $\% 20$ Marginal $\% 20$ Cost $\% 20$ of $\% 20$ Water\%20in\%20SA\%20-\%20FINALPDF> (Accessed 6 June 2011).

DWA (DEPARTMENT OF WATER AFFAIRS, SOUTH AFRICA) (2010g) Vaal River WRDP: Comparative Study between LHWP II and Thukela Water Project: Economic Comparison Report. Report No. P RSA C000/00/12009/4. Department of Water Affairs, Pretoria.

DWAF (DEPARTMENT OF WATER AFFAIRS AND FORESTRY, SOUTH AFRICA) (1999) Mkomazi-Mgeni Transfer Scheme Prefeasibility Study: Main Report. Report No. PB1 U100-00-0499. Department of Water Affairs and Forestry, Pretoria.

DWAF (DEPARTMENT OF WATER AFFAIRS AND FORESTRY, SOUTH AFRICA) (2001) Vaal River system analysis update: Summary report. Report No. PC 000/00/19496. Department of Water Affairs and Forestry, Pretoria.

HOWARD RA (1980) An assessment of decision analysis. Oper. Res. 28 (1) 4-27.

MARSDEN JACOB ASSOCIATES (2007a) An economic evaluation of the proposed Traveston Crossing Dam in South East Queensland. Report prepared for Queensland Water Infrastructure Pty. Ltd. Final Report. 7 September 2007.

MARSDEN JACOB ASSOCIATES (2007b) An economic evaluation of the proposed Wyaralong Dam in South East Queensland. Report prepared for Queensland Water Infrastructure Pty. Ltd. Final Report. 2 October 2007.

MATHESON JE and HOWARD RA (1983) An introduction to decision analysis. In: Howard RA and Matheson JE (eds.) Readings on the Principles and Applications of Decision Analysis. Vol. 1. Strategic Decisions Group, Menlo Park, CA. 17-56.

QUEENSLAND GOVERNMENT (2006) Water for South East Queensland - A Long Term Solution. August. URL: http://www. google.com/search?q=Queensland+Government $\% 2 \mathrm{C}+2006 \% 2 \mathrm{C}+$ Water+for+South+East+Queensland+\%E2\%80\%93+A+Long+Ter $\underline{\mathrm{m}+\text { Solution\%2C+August.\&sourceid=ie7\&rls=com. microsoft:en- }}$ US\&ie $=u t f 8 \& o e=u t f 8 \& r l z$ (Accessed 17 Oct 2011).

QUEENSLAND WATER COMMISSION (2010) South East Queensland Water Strategy. Queensland Water Commission. URL: http://www.qwc.qld.gov.au/security/pdf/seqws-full.pdf (Accessed 17 October 2011).

SNADDON CD, DAVIES BR and WISHART MJ (1999) A Global overview of inter-basin water transfer schemes, with an appraisal of their ecological, socio-economic and socio-political implications, and recommendations for their management. WRC Report No. TT 120/00. Water Research Commission, Pretoria.

TCTA (TRANS CALEDON TUNNEL AUTHORITY, SOUTH AFRICA) (2009) Mooi-Mgeni Transfer Scheme - Phase 2: Selection of water transfer system. Report TCTA 04-041. TCTA, Pretoria.

TRIEBEL C and VAN NIEKERK PH (1994) The Water Supply Systems in South Africa. In: Jordaan J (Jr) (ed.) Large dams and Water Systems in South Africa. SANCOLD, Pretoria. 30-43.

VAN NIEKERK PH (2013) Hydrologic-economic appraisal of interbasin water transfer projects. PhD thesis, Stellenbosch University. URL: http://hdl.handle.net/10019.1/79887.

VAN ROOYEN J and VERSFELD D (2010) Integrated Water Resource Planning For South Africa: A Situation Analysis 2010. Report No. P RSA 000/00/12910. URL: http://www.dwaf.gov.za/Documents/ Other/Water\%20Resources/IntegratedWRPlanningSA-2010.PDF (Accessed 11 April 2011).

VAN ROOYEN P (2012) LHWP Operating Scenario Information and calculations. Personal communication (e-mail to P van Niekerk), 20 February 2012. Title, name, position, affiliation/organisation, postal address.

WORLD BANK (1997) Staff Appraisal Report: China Wanjiazhai Water Transfer Project. Report No. 15999-CHA. World Bank, Washington DC. URL: <http://www-wds.worldbank.org/external/ default/WDSContentServer/WDSP/IB/1997/05/12/000009265_3 970818102240/Rendered/PDF/multi page.pdf $>$ (Accessed 11 July 2011).

WORLD BANK (2007) Implementation completion and results report on a loan in the amount of US $\$ 325$ million to the People's Republic of China for the Wanjiazhai Water Transfer Project. (IBRD-41790). 21 December 2007. URL <http://www-wds. worldbank.org/external/default/WDSContentServer/WDSP/ IB/2008/07/14/000333037 20080714034447/Rendered/INDEX/ ICR6860Box03271isclosed0June9020081.txt (Accessed 11 July 2011). 